\title{
Rethinking welfare history through a transnational and global lens. A gender-focused analysis of the Italian case
}

\author{
Silvia Inaudi*
}

This article examines recent Italian historiography on welfare, with a particular focus on gender-oriented research. It relates recent Italian studies to the international debate, in order to identify acquisitions, open problems and perspectives. Its aim is to show how these studies could improve if a transnational and, broadly speaking, global approach was adopted, and it discusses a series of possible themes and issues to be addressed.

Key words: Welfare State, Gender, Transnational and Global History, Italy

\section{Welfare history and the challenges of the global and transnational approach}

Welfare continues to be considered - from many points of view - a topic deeply anchored not only in national cases, but also in the nation-state category itself. For this reason, welfare and, more generally, social politics are struggling to be included in the preferred research areas of the new, global strand of historiography. If the way the purists of global history are looking at welfare history seems reductive, it must be said that the majority of the historians of welfare itself, with a few important exceptions, ${ }^{1}$ remain largely indifferent to world history, and to global history at large. Besides, while the comparative approach has often fruitfully been adopted by the historiography of welfare, the transnational perspective has not yet fully been embraced. However, recent research has shown the benefits of going beyond the focus of the nation-state, viewed in terms of a hypostatic and a static entity. ${ }^{2}$ It seems to me that, when

* Assegnista di ricerca, Scuola Normale Superiore di Pisa; silvia.inaudi@sns.it

${ }^{1}$ Kiran Klaus Patel, The new deal. A global history, Princeton, Princeton University Press, 2016; Alvin Finkel, Compassion. A global history of social policy, London, Red Globe Press, 2019.

${ }^{2}$ On this see Daniel Rodgers, Dallo spazio al movimento, "Contemporanea", 2004, n. 1, pp. 99-106; Pauli Kettunen, Klaus Petersen, Introduction: rethinking welfare state models, in 
faced with the challenges of the global and transnational approach, a genderfocused analysis can offer important insights to develop new directions in welfare history.

Over the last decades, gender studies on welfare politics have increased dramatically, to such an extent that it is both difficult to quantify them and impossible to discuss them in this article. Indeed, a long time has passed since the publication of the studies of Lewis and Sainsbury, ${ }^{3}$ who lamented the complete absence of a gender-oriented approach in key publications such as those by Esping-Andersen. ${ }^{4}$ It has become ever more difficult for scholars of all disciplines to avoid confronting themselves with a similar perspective. ${ }^{5}$ With specific regard to the historical discipline, women's and gender history have certainly been more inclined than other historiographical currents to engage in comparative, international, connected and transnational history, ${ }^{6}$ and more recently also in global history, despite difficulties and suspicions harboured by both approaches. It is precisely welfare that emerges as one of the growing topics in gender analyses that adopt similar historiographical perspectives. ${ }^{8}$

Studies conducted from a gender perspective - not least those of a comparative nature - have undoubtedly formed the basis of analyses that have changed the categories of the historical dynamics of welfare and enhanced the understanding of these. The so-called maternalist approach has definitely obtained the most significant results; over the years, it has been widely discussed and it has acquired different nuances, up to the point of broadening into studies that maintain very feeble connections with studies about the welfare state. ${ }^{9}$ Now

Pauli Kettunen, Klaus Petersen (eds.), Beyond welfare state models. Transnational historical perspectives on social policy, Cheltenham, Northampton, Edward Elgar Publishing, 2011; Cristoph Conrad, Pour une histoire des politiques sociales après le tournant transnational, in Axelle Brodiez-Dolino, Bruno Dumons (eds.), La protection sociale en Europe au XXe siècle, Rennes, PUR, 2014.

${ }^{3}$ Jane Lewis, Gender and the development of welfare regimes, "Journal of European Social Policy", 1992, n. 3, pp. 159-173 and Ead., Gender and welfare regimes: further thoughts, "Social Politics", 1997, n. 4, pp. 160-117; Diane Sainsbury (ed.), Gendering welfare states, Newbury Park, Sage, 1994.

${ }^{4}$ Gosta Esping-Andersen, The three worlds of welfare capitalism, Princeton, Princeton University Press, 1990.

${ }^{5}$ In 2009, the same Esping-Andersen published a study entirely dedicated to the relation between women and welfare. See Gosta Esping-Andersen, Incomplete revolution: adapting welfare states to women's new roles, Cambridge, Polity Press, 2009.

${ }^{6}$ Oliver Janz, Daniel Schönpflug, Introduction, in Ead. (eds.), Gender history in a transnational perspective. Networks, biographies, gender orders, New York; Oxford, Berghahn, 2014.

${ }^{7}$ Angelika Epple, Storia globale e storia di genere: un rapporto promettente, "Storia e regione", 2012, n. 1-2; Merry Wiesner-Hanks, Gender history and global history: borders and intersections, "L'Homme", 2012, n. 2.

${ }^{8}$ O. Janz, D. Schönpflug, Introduction, p. 1.

${ }^{9}$ Gisela Bock, Pat Thane (eds.), Maternity and gender policies. Women and the rise of the European welfare states, 1880s-1950s, New York, Routledge, 1991; Seth Koven, Sonya Michel (eds.), Mothers of a new world. Maternalist politics and the origins of welfare states, New York, 
even this category is being re-examined, if not openly put into question by the studies of researchers on (and often coming from) the East, Asia, and Central and South America. Thanks to the emergence of a new generation of female scholars,${ }^{10}$ new questions emerged following the dissolution of the Soviet Union and the downfall of the socialist states in Eastern Europe and Central Asia, especially with regard to the concepts of democracy, free market and consumption, and citizenship - all questions that directly concern welfare history. ${ }^{11}$ The maternalist category, like that of familism, is thus redefined and updated to better adhere to societies that have seen welfare politics being developed in more recent times, as opposed to most Western countries, and in radically different social and cultural contexts, where the application of models such as that of the male breadwinner proves to be inadequate. Additionally, even in this area of research, the problems generated by transformations in presentday society (e.g. globalisation, migratory fluxes, changes in family structures and the job market, the progressively aging population), in which women are subjected to continuous challenges and tensions, raise new questions and doubts that cannot but impact on the very nature of the research.

Moreover, to deal with the topic of welfare in a transnational perspective is by no means an easy task. In the first place, there is an intrinsic complexity typical of many objects of historical research - that goes beyond the national dimension. The difficulty of mastering multiple languages and analysing primary sources held in various locations might lead to attempts to draw comparisons based exclusively on secondary sources (which have fortunately become more accessible thanks to the internet and digitalisation processes). This is even more so for Italy, where global and world history studies are being conducted despite many difficulties, including economic ones; it is not a surprise that they are being often carried forward by Italian scholars based in foreign universities. ${ }^{12}$ Paradoxically, the shift from a mainly political and legal analysis to a fully historical approach to welfare could lead to a setback in research, given that one of the determining factors for a proper understanding of welfare is archival research. ${ }^{13}$

In second place, there are also methodological difficulties, starting from the problem of terminology; it is not always easy to find a translation that

Routledge, 1993; Karen Mead, Beneficent maternalism: Argentine motherhood in comparative perspective, 1880-1920, "Journal of Women's History", 2000, n. 3, pp. 120-145; Marian van der Klein et al. (eds.), Maternalism reconsidered. Motherhood, welfare and social policy in the twentieth century, Oxford, New York, Berghahn Books, 2012.

${ }^{10}$ In this context I intentionally make reference to female scholars, given that the majority of these studies is the work of female researchers.

${ }^{11}$ Bonnie G. Smith, Introduction, in Bonnie G. Smith (ed.), Women's history in global perspective, vol. II, Urbana \& Chicago, University of Illinois Press, 2005, p. 3.

${ }_{12}^{12}$ Marco Meriggi, Intervento sulla world history, "Giornale di storia", 2015, n. 17, p. 5-6.

${ }_{13}$ Paolo Mattera, Global e welfare: bilanci e prospettive per la storia sociale del lavoro, "Società e storia", 2019, n. 163, p. 127. 
can reflect specific implications and complexities. Think, for example, of the polysemous concept of maternità, which in English-language countries is often translated - with varying nuances - as motherhood and maternity. ${ }^{14}$ More generally speaking, words such as family, work, politics and the very concept of the nation, have different meanings and imply different strategies the moment one crosses the boundaries of the West. ${ }^{15}$ Yet, we must take into account - as Laura Downs recalls - that often "national culture and differences in state structures defined distinctive routes to what were, in many important respects, rather similar outcomes." ${ }^{.16}$ In many cases, in social politics as in other areas, this outcome is the continuation of gender inequality.

Thirdly, when it comes to the actual historiographical product, the results tend to thin out as the perspective gradually widens. In the summaries dedicated to the issue of gender in world history publications, the themes of welfare and social politics either are not present or resurface to the background of studies about family, sexuality, work and education at a global level, given the obvious connections between welfare and these areas. ${ }^{17} \mathrm{~A}$ first attempt at synthesis is that offered in the section Welfare State of the Oxford Encyclopedia of Women in World History ${ }^{18}$ whereas themes related to social politics and welfare also appear in The Palgrave Dictionary of Transnational History, albeit not in a substantial way. ${ }^{19}$ Moreover, summaries - like macrohistorical analyses - risk creating inappropriate generalisations, especially in an area such as welfare. The most ambitious studies, as is evident in the case of analyses of maternalism, frequently present themselves as overviews of research conducted by female scholars from various countries, aimed at enriching — by offering a complete reading — the vast body knowledge of different geographical areas. The same modality is adopted in the first collective works that seek to widen the perspective beyond the West. ${ }^{20}$

${ }^{14}$ On this aspect see Anne Taylor Allen, Lost in translation? Un regard transnational et comparatiste sur l'histoire des femmes, in Anne Cova (ed.), Histoire comparée des femmes, Lyons, ENS Édition, 2009.

${ }^{15}$ B.G. Smith, Introduction, p. 3.

${ }^{16}$ Laura Lee Downs, Manufacturing inequality. Gender division in the French and British metalworking industries, 1914-1939, Ithaca and London, Cornell University Press, 1995, p. 12.

${ }^{17}$ See, for example, Teresa A. Meade, Merry E. Wiesner-Hanks (eds.), A companion to gender history, Malden, Oxford, Blackwell, 2004 and Peter N. Stearns, Gender in world history, New York, Routledge, 2006 (2. Ed.). See also the volumes dedicated to the nineteenth and twentieth centuries of the World history recently translated by Einaudi (Cfr. Storia del mondo, 6 voll., Turin, Einaudi, 2015).

${ }_{18}$ Denys P. Leighton, Mary Lynn Stewart, Welfare state, in Bonnie G. Smith (ed.), The Oxford encyclopedia of women in world history, Oxford University Press, New York, 2008.

${ }^{19}$ Akira Iriye, Pierre Yves Saunier (eds.), The Palgrave dictionary of transnational history. From the mid-19th century to the present day, Basingstoke, Palgrave Macmillan, 2009.

${ }^{20}$ See, for example, Lynne Haney, Lisa Pollard (eds.), Families of a new world. Gender, politics, and state development in a global context, New York, Routledge, 2003 and Ellen Fleischmann et al. (eds.), Transnational and historical perspectives on global health, welfare and humanitarianism, Kristiansand, Portal Books, 2013. 
Nevertheless, to conduct an analysis from a global and transnational perspective seems to be less common in mainland and southern Europe (with the important exception of Germany) than it is in American or British historiography. Hence, a large part of historical research on the welfare state that has been conducted in European countries, be it in a gender perspective or not, continues to focus on national contexts or limits itself to comparisons between two or more - very often Western — countries. ${ }^{21}$

\section{Italian historiography and new trends}

What, then, is the situation in Italy? What is happening in the historiography of welfare? To answer these questions, we must take a number of premises into account. The study of the welfare state in the historical discipline is a relatively recent phenomenon; for a long time, analyses of welfare - especially those of general or comparative nature - have remained the exclusive prerogative of sociologists, political scientists, legal experts and economists. ${ }^{22}$ This is even more so if we look at the Italian case. ${ }^{23}$ The first studies from a historical perspective began to develop in the 1980s, but it was not until the second half of the 1990s that they increased in number, focusing on specific historical periods such as Fascism. ${ }^{24}$ The first attempts were made at a historical synthesis, including by putting Italian welfare into perspective and comparing

${ }^{21}$ Anne Cova, Introduction. Les promesses de l'histoire comparée des femmes, in A. Cova, Histoire comparée des femmes, pp. 24-27; C. Conrad, Pour une histoire des politiques sociales après le tournant transnational, p. 77.

${ }^{22}$ Gerald Albert Ritter, Storia dello Stato sociale, Rome-Bari, Laterza, 1996, p. 32.

${ }^{23}$ In this article it is impossible to take into account the extremely vast production on Italian welfare in the social sciences. The following are among the most important studies: Ugo Ascoli (ed.), Welfare state all'italiana, Bologna, il Mulino, 1984; Maurizio Ferrera, Il welfare state in Italia. Sviluppo e crisi in prospettiva comparata, Bologna, il Mulino, 1984; Valeria Fargion, Geografia della cittadinanza sociale in Italia. Regioni e politiche assistenziali dagli anni Settanta agli anni Novanta, Bologna, il Mulino, 1997; Fiorenzo Girotti, Welfare State. Storia, modelli e critica, Rome, Carocci, 1998; Maurizio Ferrera, Valeria Fargion, Matteo Jessoula, Alle radici del welfare all'italiana. Origini e futuro di un modello sociale squilibrato, Venice, Marsilio, 2012; Ugo Ascoli, Emmanuele Pavolini (eds.), The Italian welfare state in a European perspective. A comparative analysis, Bristol, Policy, 2015. Studies conducted from a gender perspective include: Alisa Del Re (ed.), I rapporti sociali di sesso in Europa 19301960. L'impatto delle politiche sociali, Padua, Cedam, 1991; Chiara Saraceno, The ambivalent familism of the Italian welfare state, "Social Politics. International Studies in Gender, State \& Society", 1994, n. 1, pp. 60-82; Franca Bimbi (ed.), Le madri sole. Metafore della famiglia ed esclusione sociale, Rome, Carocci, 2000; Manuela Naldini, The family in the mediterranean welfare state, London; New York, Routledge, 2003.

${ }^{24}$ Paolo Mattera, Introduzione: la storia del welfare state in Italia, quali basi e quali prospettive?, in Paolo Mattera (ed.), Momenti del welfare in Italia. Storiografia e percorsi di ricerca, Rome, Viella, 2012, p. 15. 
it with the main European systems..$^{25}$ The areas of analyses were originally more focused on systems of social security, ${ }^{26}$ albeit with some important exceptions, ${ }^{27}$ and subsequently extended to the sectors of social care ${ }^{28}$ and social work (with the inauguration of a book series promoted by the Society for the History of Social Work, published by Viella), ${ }^{29}$ to the health sector, ${ }^{30}$ and to that of housing policies. ${ }^{31}$ Additionally, emphasis has been placed on the count-

${ }^{25}$ Enzo Bartocci, Le politiche sociali nell'Italia liberale, Rome, Donzelli, 1999; Gianni Silei, Lo Stato sociale in Italia. Storia e documenti, 2 voll., Manduria, Lacaita, 2003-2004; Fulvio Conti, Gianni Silei, Breve storia dello Stato sociale, Rome, Carocci, 2005; Andrea Rapini, Lo Stato sociale, Bologna, Archetipolibri, 2010. As this article goes to print a comprehensive study has been published: Chiara Giorgi, Ilaria Pavan, Storia dello Stato sociale in Italia, Bologna, il Mulino, 2021.

${ }^{26}$ Arnaldo Cherubini, Storia della previdenza sociale in Italia 1860-1960, Rome, Editori Riuniti, 1977; Dora Marucco, Lavoro e previdenza dall'unità al fascismo. Il Consiglio della previdenza dal 1869 al 1923, Milan, FrancoAngeli, 1984; Istituto nazionale della previdenza sociale, Novant'anni di previdenza in Italia: culture, politiche, strutture (Conference Proceedings, Rome, 9/10 November 1988), Rome, Inps, 1989, which has been complemented by a more recent study by Chiara Giorgi, La previdenza del regime. Storia dell'Inps durante il fascismo, il Mulino, Bologna, 2004.

${ }^{27}$ Domenico Preti, La modernizzazione corporativa (1922-1940). Economia, salute pubblica, istituzioni e professioni sanitarie, Milan, FrancoAngeli, 1987; Stefano Lepre, Le difficoltà dell'assistenza. Le opere pie in Italia fra '800 e '900, Rome, Bulzoni, 1988.

${ }^{28}$ See, among others: Giovanna Farrell-Vinay, Povertà e politica nell'Ottocento. Le opere pie nello Stato liberale, Turin, Scriptorium, 1997; Stefano Sepe, Le amministrazioni della sicurezza sociale nell'Italia unita, 1861-1998, Milan, Giuffrè, 1999; Silvia Inaudi, A tutti indistintamente. L'Ente opere assistenziali nel periodo fascista, Bologna, Clueb, 2008; although written by a non-Italian scholar, we must also mention Maria Sophia Quine, Italy's social revolution: charity and welfare from Liberalism to Fascism, Basingstoke, Palgrave, 2002. From the early 2000s onwards, an analysis of this topic that pays attention to the republican period has been promoted by the "Bollettino dell'Archivio per la storia del movimento sociale cattolico in Italia" (cfr. Giampiero Fumi, L'assistenza nell'Italia del dopoguerra: un nuovo progetto di lavoro dell'Archivio, "Bollettino dell'Archivio per la storia del movimento sociale cattolico in Italia", 2002, n. 1, pp. 11-19); see, in particular, the special issue edited by Anne Cova and Michela Minesso, Welfare in Italia nel secondo dopoguerra. L'assistenza (1945-1968), 2013, n. $1-2$.

${ }^{29}$ Among the studies published thus far see, in particular: Maria Stefani (ed.), Le origini del servizio sociale italiano. Tremezzo: un evento fondativo del 1946. Saggi e testimonianze, Rome, Viella, 2012; Enrico Appetecchia (ed.), Idee e movimenti comunitari. Servizio sociale di comunità in Italia nel secondo dopoguerra, Rome, Viella, 2015; Marilena Dellavalle, Elisabetta Vezzosi (eds.), Immaginare il futuro. Servizio sociale di comunità e community development in Italia (1946-2017), Rome, Viella, 2018.

${ }^{30}$ Saverio Luzzi, Salute e sanità nell'Italia repubblicana, Rome, Donzelli, 2004; Chiara Giorgi, Ilaria Pavan, Un sistema finito di fronte a una domanda infinita. Le origini del Sistema sanitario nazionale italiano, "Le Carte e la Storia", 2018, n. 2, pp. 103-117; Ead., Le lotte per la salute in Italia e le premesse della riforma sanitaria. Partiti, sindacati, movimenti, percorsi biografici (1958-1978), "Studi Storici", 2019, n. 2, pp. 417-456.

${ }^{31}$ Istituto Luigi Sturzo (ed.), Fanfani e la casa. Gli anni Cinquanta e il modello italiano di welfare state. Il piano INA-Casa, Soveria Mannelli, Rubbettino, 2002; Daniela Adorni, Davide Tabor (eds.), Inchieste sulla casa in Italia. La condizione abitativa nelle città italiane nel secondo dopoguerra, Rome, Viella, 2019. 
less, long-term interactions between the state, civil society and intermediaries, in the construction of Italian welfare..$^{32}$

Moreover, intersections already known to international historiography though almost entirely neglected in the Italian debate - have started entering the scene. These include the link between religion and welfare, which revealed how not only the church as an institution, but also Catholic thought and doctrine influenced the construction of the welfare state; ${ }^{33}$ the impact of the consumer society on the development of welfare systems; ${ }^{34}$ the cause-and-effect relationship between war and the birth of welfare..$^{35}$

One of the areas that has developed most is that regarding family politics and measures aimed at supporting maternity and childhood. ${ }^{36}$ Annarita Buttafuoco's ground-breaking research in this field had already appropriated a transnational perspective - in a broad sense - well ahead of her time; it did so by integrating itself into the strand of studies that examined the connections and exchanges between maternalist feminist groups, which were at the origin of the very first social measures in favour of women and children. ${ }^{37}$ New studies in this area have, on various occasions, adopted a comparative perspective. In particular, two books edited by Michela Minesso offer an overview of essays that is rich with suggestions on the link between the idea of citizenship

\footnotetext{
${ }^{32}$ Maurizio Degl'Innocenti, La società volontaria e solidale. Il cantiere del welfare pubblico e privato, Manduria, Lacaita, 2012; Anna Salfi, Fiorenza Tarozzi (eds.), Dalle società di mutuo soccorso alle conquiste del welfare state, Rome, Ediesse, 2014.

${ }^{33}$ Edoardo Bressan, Le vie cristiane della sicurezza sociale. I cattolici italiani e il welfare state, in Andrea Bassi, Birgit Pfau-Effinger (eds.), Lo spirito del welfare, special issue of "Sociologia e politiche sociali", 2012, n. 3, pp. 91-120.

${ }^{34}$ Patrizia Battilani, Claudio Benassi (eds.), Consumare il welfare. L'esperienza italiana del secondo Novecento, Bologna, il Mulino, 2013.

${ }^{35}$ Giovanna Procacci, Warfare-welfare. Intervento dello Stato e diritti dei cittadini 19141918, Carocci, Rome. 2013; Ilaria Pavan, War and the welfare state: the case of Italy, from WWI to Fascism, "Historia contemporanea", 2019, n. 3, pp. 835-872.

${ }^{36}$ Stefania Bernini, Family life and individual welfare in post-war Europe. Britain and Italy compared, Basingstoke-New York, Palgrave, 2007; Maurizio Bettini, Stato e assistenza sociale in Italia. L'Opera Nazionale Maternità e Infanzia, 1925-1975, Erasmo, Livorno; 2008; Michela Minesso, Stato e infanzia nell'Italia contemporanea. Origini, sviluppo e fine dell'Onmi. 19251975, il Mulino, Bologna, 2007; Michela Minesso (ed.), Welfare e minori. L'Italia nel contesto europeo del Novecento, Milan, FrancoAngeli, 2011; Elisabetta Vezzosi, Maternalism in a paternalist state: the National Organization for the Protection of Motherhood and Infancy in Fascist Italy, in M. van der Klein et al. (eds.), Maternalism reconsidered, pp. 190-204; Domenica La Banca, Welfare in transizione. L'esperienza dell'Onmi (1943-1950), Naples, Ed. Scientifiche italiane, 2013; Dorena Caroli, Per una storia dell'asilo nido in Europa tra Otto e Novecento, Milan, FrancoAngeli, 2013; Michela Minesso, Madri figli welfare. Istituzioni e politiche dall'Italia liberale ai giorni nostri, Bologna, il Mulino, 2015; Michela Minesso (ed.), Welfare, donne e giovani in Italia e in Europa nei secoli 19.-20., Milan, FrancoAngeli, 2015.

${ }^{37}$ Annarita Buttafuoco, Motherhood as a political strategy: the role of the Italian women's movement in the creation of the Cassa Nazionale di Maternità, in G. Bock, P. Thane (eds.), Maternity and gender policies, and Ead., Le origini della Cassa Nazionale di Maternità, Siena, Università degli Studi, 1992.
} 
and various advancements in social politics regarding women, childhood, and youth, in a European context. ${ }^{38}$

An interesting example of an analysis that advances a comparative and multidisciplinary dialogue is the book edited by Nunin and Vezzosi, titled Donne e famiglie nei sistemi di welfare [Women and families in welfare systems]. In this study, macro and micro perspectives intertwine, and the history of welfare is reconsidered from a gender perspective. In doing so, it opens up to the new issues that, from the early 2000s onwards, have dominated analyses of social politics: the transition from a male breadwinner to a dual breadwinner model; globalisation and transformation of the job market; the progressively aging population; new migrations; the current tension between economic and social citizenship. ${ }^{39}$

The need to overcome the national perspective in Italian welfare studies was recently made explicit in a special issue of the "Journal of Modern Italian Studies", edited by Paolo Mattera and Ilaria Pavan. ${ }^{40}$ It contained essays that approached the evolution of republican welfare from a comparative perspective and in terms of the circulation and influence of European (i.e. English, French, Scandinavian) and international (Oil) ideas and models. The analyses contained in the special issue offer a valid example of the essential quality of a supranational approach in the acquisition of new knowledge in this area. To measure oneself against a, if not global then at least, transnational dimension therefore represents a further step that deserves to be taken, difficult and insidious as it may be. Only thus can we permanently subtract welfare history from the danger of staying trapped in an interpretation of (negative) exceptionalism, starting with those elements that - for decades now - have been identified as some of its principal characteristics: the excessive weight of private institutions, especially those of confessional nature; the continuity of fascist institutions in the republican period; ambivalent familism; degeneration related to clientelism. ${ }^{41}$

Although the prolific production of recent years promises well, it must nevertheless be stressed that the history of social politics, and gender-oriented history perhaps even more, continues to represent a fringe topic in the Italian historiographical horizon, if compared to decidedly more mainstream historical subjects and currents. Moreover, the majority of research in this area remains

${ }^{38}$ M. Minesso (ed.), Welfare e minori, and Ead. (ed.), Welfare, donne e giovani in Italia e in Europa nei secoli 19.-20.

${ }^{39}$ Roberta Nunin, Elisabetta Vezzosi (eds.), Donne e famiglie nei sistemi di welfare. Esperienze nazionali e regionali a confronto, Rome, Carocci, 2007.

${ }^{40}$ Paolo Mattera, Ilaria Pavan (eds.), The Italian welfare state in a supranational perspective: history and debates, special issue of the "Journal of Modern Italian Studies", 2017, n. 2.

${ }^{41}$ For an in-depth analysis of this theme, within the specific context of social assistance, I take the liberty to cite an article of my own: L'assistenza nel secondo dopoguerra tra continuità e mancate riforme. Note a margine del dibattito storiografico, "Storica", 2010, n. 46, pp. 79-99. 
focused on local contexts. This does not necessarily impede a widening of the horizon where a glocal perspective - in its reconsideration (if not total overturning) of the relations between centre and periphery — can shed light on the connection between the two dimensions and retrieve its complexity even more effectively. Indeed, the very study of local, provincial and regional levels which is fundamental for an understanding of Italian history - has reconsidered the apparent coherence of the nation-state: certainly of its origins, but not only, as demonstrated by Laura Lee Downs's research, for example, on aspects of social welfare for children in a traditionally "strong" state context, as is the French one. ${ }^{42}$

To conclude my observations about the framework in which historical research is located, I should add that the difficulties - not to mention impenetrability - inherent in the interdisciplinary dialogue (aside from the already mentioned exceptions) that still marks Italian academia in so many ways certainly do not help welfare historians; given the very characteristics of the subject in question, scholars can and must draw part of their lifeblood precisely from multidisciplinarity.

\section{Research perspectives}

This long, and inevitably incomplete, preliminary overview has served to demonstrate that, in the Italian context, too, the historical analysis of welfare can expand its horizon and take a further step beyond both national history and comparative history. In this way, it can trace the transnational connections and universal frameworks of cultural interrelation in which the nation-states have operated. Nevertheless, we must remain conscious of the undeniable continuity of the nation-state's importance for the creation of similar politics, and of the risks involved in forgetting how nation-states have structured, and continue to structure, women's lives. ${ }^{43}$

One of the most urgent actions that welfare historians must take to free themselves from the trammels of an essentially national context is that they pay attention to the mechanisms of circulation, debate, exchange, reciprocity and the adaptation of knowledge, models, legislation, and administrative procedures, which permeate the origin and development of social systems at an international level. From this point of view, gender studies turn out to be privileged, as I have already stressed, since this dimension has always been present, even in "not suspicious" times.

\footnotetext{
${ }^{42}$ Laura Lee Downs, Histoire des colonies de vacances de 1880 à nos jours, Paris, Editions Perrin, 2009.

${ }^{43}$ Susan Pedersen, Family, dependence, and the origins of the welfare state: Britain and France, 1914-1945, New York, Cambridge University Press, 1993, p. 124.
} 
The discussion about, and adaptation of, welfare models has played an important role in Italy as well: if the Bismarck and the Beveridge models the latter established during the second post-war period - represent the most known and studied models, ${ }^{44}$ Belgian influences have been identified in the creation of the National Agency for Maternity and Childhood. ${ }^{45}$ In view of the methodological findings, however, it is not a question of limiting oneself to the verification of similar processes via the concepts - subjected to strong contestation - of assimilation, imitation or linear distribution. Rather, one must grasp (albeit in a context of influence) the extent to which the local reformulation has generated specific characteristics, via processes of mediating - but also by opposing - foreign models. This issue becomes even more important when compared to countries outside the West. ${ }^{46}$

The debate about legislation, administrative experiences and practices has been at the foundation of social reform conferences ever since the second half of the nineteenth century and has regularly been sustained by social movements and civil society organisations. Female movements of the late nineteenth and early twentieth centuries - whose networks, as is known, crossed national and often also European boundaries - represent the most renowned and studied examples of debate and of the use of foreign welfare models, for the purpose of pushing through reforms also in social politics. This experience is not unfamiliar to Italy, as we have seen.

During the second post-war period, in the ideological context of the Cold War, the increase in female organisations at various levels (i.e. local, national, international), whether they were of secular or religious nature, related to a party or not, has offered a ground of comparison (and dispute) in which the theme of social politics - closely connected to the growth of female labour force - represented a primary issue for the development of political strategies and agendas. With regard to the female movements of the nineteenth and early twentieth centuries, and to the feminist movements of the 1970s, this period largely remains to be explored for a better understanding of its contribution in terms of fights for women's rights, also in view of social citizenship. This is even more pertinent given that many female protagonists entered Parliament, thus contributing to keep the debate about social politics alive, as a recent study has demonstrated. ${ }^{47}$

${ }^{44}$ See, for example, Loreto Di Nucci, Alle origini dello Stato sociale nell'Italia repubblicana. La ricezione del piano Beveridge e il dibattito nella Costituente, in Carlotta Sorba (ed.), Cittadinanza. Individui, diritti sociali, collettività nella storia contemporanea, Rome, Ministero per i beni e le attività culturali, Direzione generale per gli archivi, 2002.

${ }^{45}$ M. Minesso (ed.), Stato e infanzia nell'Italia contemporanea, pp. 57-58.

${ }^{46}$ An example that regards Italy is that of the relation between the development of Japanese social politics and fascist corporate models: Bernard Thomann, Il dibattito sul "fascismo" e la riforma sociale in Giappone fino al 1945, "Contemporanea", 2008, n. 3, pp. 397-431.

${ }^{47}$ Michela Minesso, Diritti e politiche sociali. Le proposte delle parlamentari nelle assemblee legislative dell'Italia repubblicana (1946-1963), Milan, FrancoAngeli, 2016. 
Knowledge transfer also occurred in areas that have for a long time remained less open to women's presence and influence. Think, for example, of the constant exchange of information and knowledge - ever since the mid-nineteenth century - in the fields of medicine and hygiene, and in urban planning, which subsequently expanded into the social sciences (first and foremost, demography and psychology). The analysis of the contributions expert communities and networks made to the implementation of social measures in a biopolitical framework seems decisive in understanding the technocratic influence on women's bodies and lives, and, more generally, on the construction of a gender identity. Studying the transnational interconnections, rereading, and interpreting knowledge and concepts in view of national cultural contexts, especially in terms of the passage (or lack thereof) from debates to practices, may cast further light on aspects that have been neglected or have remained invisible to scholars of social politics. Take the issue of child well-being, an area in which gender and politics intersect in various ways, and often not harmoniously: one example is the transnational influence of John Bowlby's infant attachment theories during the second post-war period. ${ }^{48}$

International organisations and foundations are equally important for a contextualisation of social politics from a supranational perspective, not only in terms of knowledge transfer but also with regard to the exportation of models and practices: one example is the Rockefeller Foundation, which has had considerable global influence - and Italy is no exception - on public health issues. ${ }^{49}$ In Italy, this field remains mostly unexplored, especially if considered from a gender perspective. A study of the so-called soft law, too, may reveal itself to be particularly challenging.

No less packed with consequences are the processes linked to the development of international solidarity and humanitarianism, in response to the globalisation of problems related to wars, epidemics and famine. If the roots of this international intervention can be traced back to the mid-nineteenth century, it is undoubtedly after the global conflicts that international, public and private, organisations become exceptional agents not just of financial transfers, but also of models of modernisation (with all the ambiguity that this concept implies) in the social sector. Examples of these for Italy include the United Nations Relief and Rehabilitation Administration, ${ }^{50}$ and Unicef and the Fao for the circulation - through social care - of models of health and food education that affected the habits and behaviours of the poorest classes,

\footnotetext{
${ }^{48}$ In Italy, too, Bowlby's studies have had a considerable influence on the debate about the rights of unmarried mothers and about adoption.

${ }^{49}$ Frank M. Snowden, The conquest of malaria. Italy 1900-1962, New Haven and London, Yale University Press, 2006.

${ }^{50}$ Giacomo Canepa, The transatlantic transfers of social policies in the context of Unrra's "Rehabilitation" of post-World-War-II Italy, in Yearbook of transnational history, vol. I, Madison, Fairleigh Dickinson University Press, 2018, pp. 139-162.
} 
in particular women and children. ${ }^{51}$ These models were usually transmitted through child care providers and educators, whose relations with their beneficiaries - here as in other areas - would need to be studied more in detail.

Organisations and foundations also represented a means of mobility for the women who were active in social sector, thanks to travel grants for the study of foreign models and conference participation. Despite the difficulties involved in conducting research on people who often occupied minor positions in Italian social administration, ${ }^{52}$ the experiences of these social actors deserve more scholarly attention.

If we move from the circulation of knowledge to that of people, we must inevitably address the topic of migratory processes; as is known, these are among the preferred research areas of global and gender history, having been (and continuing to be) inextricably linked to the implementation of social politics at various levels. From this perspective, a country like Italy — which has changed from being a country of emigrants to a country of immigrants - reveals itself to be an infinite source of research possibilities. One potential study area, for example, is that of the implementation of social care services during migration; a quite important role was played by the church and related authorities, whose influence would need to be studied more in depth, also in relation to the - not necessarily predictable - processes of female emancipation linked to the very phenomenon of migration. Another possible topic is the issue of welfare services for Italians abroad, and their repercussions not only on the places of arrival, but also on those of departure. In the case of Italian migration to France, for example, it has been highlighted that the political strategies of attraction and management of migratory flows generated social politics with a "gendered" connotation (indirectly and, at times, involuntarily), through specific measures such as the payment of family allowances for offspring still present on the Italian territory, notwithstanding the territoriality principle. ${ }^{53}$ In this regard, it must be noted that differences and flexibility in terms of welfare may also have impacted on women's and men's strategies with regard to mobility, work and life choices. Finally, the relation between welfare and wage labour, unpaid or illegal work, a problem that denotes the relation between gender and welfare more generally, becomes central in the frame-

${ }^{51}$ Silvia Inaudi, Assistenza ed educazione alimentare. l'Amministrazione per gli aiuti internazionali, 1947-1965, "Contemporanea", 2015, n. 3, pp. 373-399 and Ead., "Milk is life". Nutritional interventions and child welfare: the Italian case and the post-war international aid, in David Gentilcore, Matthew Smith (eds.), Proteins, pathologies and politics. Dietary innovation and disease from the nineteenth century, London, Bloomsbury, 2018; Angela Villani, Dalla parte dei bambini. Italia e Unicef fra ricostruzione e sviluppo, Padua, Cedam, 2016.

${ }_{52}$ On the opacity that still pervades these actors, Marilena Dellavalle, Gender in Italian social work: a neglected issue, "Contemporanea", 2019, n. 2, pp. 287-294.

${ }_{53}$ Alexis Spire, Étrangers à la carte. L'administration de l'immigration en France (19451975), Paris, Grasset, 2005. 
work of migrations. This is true also in light of the way women's relations are structured: think of the example par excellence of illegal work, namely domestic service and care work, which has been and often still is a prerogative of migrant women, favouring their entry into the native-born women's world of employment, but with all the difficulties of accessing social welfare benefits that migrant women are faced with.

Another issue that concerns people's mobility, which I have only touched upon in this article, is that of colonial conquests. For Italy, these represent shorter experiences than for other countries, but not for this reason are they less important. While the export of social care and social security structures to the colonial territories by Fascism is a little-known episode, it deserves further exploration, provided sources can be accessed, also in light of the fascist projects of identity construction directed at Italian men and women in foreign territories. ${ }^{54}$

The history of welfare (but clearly not just the Italian one) can therefore only benefit from a confrontation with the suggestions offered by transnational and global history. Moreover, we will need to adopt an even broader global approach - the more so in gender-focused analyses - capable of integrating a perspective that confronts itself, in an interdisciplinary way, with the debates that are redirecting welfare studies within social sciences, starting from globalisation as a phenomenon. ${ }^{55}$ Only thus will we be able to continue doing what women's history and gender history excel in: making the invisible visible.

${ }^{54}$ Some preliminary observations about the activities of the National Fascist Institute of Social Security can be found in Pamela Ballinger, Colonial twilight: Italian settlers and the long decolonization of Libya, "Journal of Contemporary History", 2016, n. 4, pp. 817-826.

${ }_{55}$ Matthew E. Carnes, Isabela Mares, The welfare state in global perspective, in Carles Boix, Susan Stokes (eds.), The Oxford handbook of comparative politics, New York, Oxford University Press, 2007. 